\title{
Obligation in Carrying Out Administrative Effort as a Mean of Legal Protection for Justice Seekers in State Administrative Dispute in East Java
}

\author{
Sudarsono* \\ Faculty of Law, University of Brawijaya, Indonesia \\ Shinta Hadiyantina \\ Faculty of Law, University of Brawijaya, Indonesia \\ Dewi Cahyandari \\ Faculty of Law, University of Brawijaya, Indonesia \\ Syofyan Hadi \\ Faculty of Law, University of Brawijaya, Indonesia
}

\begin{abstract}
One of the spaces to realize legal protection, specifically repressive legal protection, can be performed through legal efforts to court. Legal protection is absolute because it is a space that ensures equal position between people and government in a country. The State Administrative Court has the authority to adjudicate, examine, decide upon and resolve government administrative disputes after administrative efforts have been taken. The court checks, hears, decides, and settles government administrative disputes according to the provisions of the procedural law in force in the court unless it is stated otherwise in the provisions of the applicable laws and regulations. Administrative efforts are one form of legal protection for justice seekers as regulated in Law No. 5 of 1986 concerning State Administrative Court, Law No. 30 of 2014 concerning Government Administration, Supreme Court Regulation No. 6 of 2018 concerning Guidelines for Resolution of Government Administrative Dispute After Taking Administrative Effort, Supreme Court Regulation No. 2 of 2019 concerning Guidelines for Resolution of Disputes over Government Actions and Authority in Judging Unlawful Actions by Government Agencies and/or Officials (onrechmatige Overheidsdaad).
\end{abstract}

Keywords: administration, legal protection, justice, state administrative dispute

DOI: $10.7176 / \mathrm{JLPG} / 92-11$

Publication date: December $31^{\text {st }} 2019$

\section{Introduction}

One of the spaces to realize legal protection, specifically repressive legal protection, can be carried out through legal efforts to court. In state administrative disputes, repressive legal protection can be submitted to the State Administrative Court.

State Administrative Court is a judicial institution that has attributive authority given by Law No. 5 of 1986 concerning State Administrative Court as replaced by Law No. 51 of 2009 which expressly states that the State Administrative Court is authorized to adjudicate state administrative disputes. That is a dispute arising in the field of state administration between a person or a legal entity and a legal entity or official.

State Administration, both at the central and regional levels, as a result of the issuance of State Administration Decrees, is included in employment disputes that are based on applicable laws and regulations. ${ }^{1}$ In this case, justice seekers who feel disadvantaged by the decision of the state administration official may submit legal remedies to the State Administrative Court and/or the State Administrative High Court.

However, before submitting legal proceedings to the State Administrative Court, justice seekers must first submit administrative efforts. Administrative efforts are those that are processed administratively by government institutions. According to Soemaryono, administrative effort is a complete assessment of a state administration decision in terms of legality (rechtmatigheid) and opportunity (doelmatigheid). ${ }^{2}$ Administrative efforts are divided into two consisting of administrative objections and administrative appeals. Administrative appeals are resolutions of state administrative disputes carried out by superiors or other agencies from issuing disputed provisions. Meanwhile, the objection procedure is the resolution of a state administration dispute carried out by the issuing agency. ${ }^{3}$

\footnotetext{
${ }^{1}$ Article 1 point 4 of Law No. 5 of 1986 concerning State Administrative Court (State Gazette of the Republic of Indonesia No. 4380)

${ }^{2}$ Soemaryono and Anna Erliyana, Guidance for Prosedural Practices in State Administrative Court, (Jakarta: PT Pramedya Pustaka, 1999), page 8

${ }^{3}$ Ridwan, Three Dimensions of Administrative Law and Administrative Justice, (Yogyakarta: FH UII Press, 2009), page 168
} 
The position of administrative efforts for justice seekers, before submitting the case to the court, is mandatory. Evidence that administrative effort is an obligation can see examples of some state administrative disputes that require a person to go through the administrative process first. In Law No. 10 of 2016 concerning regional head elections for instance, in the event of a state administration dispute in the regional head election, the legal process must be initiated by submitting administrative efforts to the Election Supervisory Board (Bawaslu). Obligations for administrative efforts are more specifically regulated in Supreme Court Regulation No. 6 of 2018 concerning Guidelines for Resolution of Government Administrative Disputes after Taking Administrative Efforts. ${ }^{1}$ When administrative efforts are required, it will raise two fundamental issues. First is whether or not the administrative effort required before making legal efforts to the State Administrative Court only puts the process of seeking justice for justice seekers further extending the bureaucratic or convoluted process. Second is what administrative efforts are effective in filtering cases that can be submitted or tried by the State Administrative Court. From this point on, it is essential to examine the background of why administrative efforts are required and how their relationships or successes in filtering cases can be brought to the State Administrative Court. Therefore, this paper discusses two problem formulations; i.e. 1. Why must administrative efforts be made before the judicial process in state administrative disputes? 2. Is the obligation to carry out administrative efforts effective in filtering cases before going to the State Administrative Court? The formulation of this problem is answered by using juridical-empirical research through a sociological approach by observing the reality on the ground related to administrative efforts.

\section{Discussion}

Legal protection is an element that cannot be ruled out in state life. The existence of legal protection is absolute because it is a space that ensures the existence of the same position between the people and the government in a country. In a country, the government is an apparatus that is given the authority to run the wheels of government and to ensure that the people do not get arbitrary treatment or are harmed by the use of that governmental authority. Therefore, the people must be provided space to carry out resistance or legal remedies if they feel disadvantaged by the implementation/use of authority carried out by the government. At the same time, legal protection can also be defined as a form of state protection for the interests of its people/citizens. Several figures provide views on legal protection as follows:

a. Satjito Raharjo: legal protection is how to allocate power for someone to act on the basis of Human Rights (HR) as an effort to protect their interests. ${ }^{2}$

b. Muktie Fadjar: legal protection is only limited to protection by law which once also contained the rights and obligations of humans as legal subjects in their interactions. ${ }^{3}$

c. C.T. Kansil: legal protection is an effort to provide a sense of security both physically and mentally to the people given by law enforcement officers. ${ }^{4}$

d. Setiono: legal protection is interpreted as an effort to create order and peace for humans to enjoy their dignity as human beings. This can be achieved by protecting the public from arbitrary acts by the authorities that are not in accordance with the rule of law.

According to Andi Hamzah and Simanjuntak, the elements of legal protection consist of:

a. The government provides protection for its community or citizens;

b. The government provides guarantees for legal certainty;

c. Legal protection relates to the rights of citizens or the community;

d. Violators are given or received sanction. ${ }^{5}$

In Indonesia, legal protection exists in all areas of criminal, civil and administrative law. In the realm of administrative law, legal protection is given to justice seeker in state administrative disputes.

State administrative disputes are disputes that occur in the administration of government. State administrative disputes occur because state administrative agencies/officials take actions or do not take actions that are detrimental to the people. Therefore, state administrative disputes are disputes that occur between administrative agencies/officials as defendants and justice seekers as plaintiffs.

Normatively, the definition of the state administrative dispute has been determined in Article 1 point 10 of Law No. 51 of 2009 which determines that:

"State administrative disputes are disputes that occur in the field of State Administration between civil persons or legal entities and State Administration agencies or officials at the central as well as regional levels, as

\footnotetext{
${ }^{1}$ Supreme Court Regulation No. 6 of 2018 concerning Guidelines for Resolution of Administrative Disputes in Government after Taking Administrative Efforts (State Gazette No. 1586 in 2018)

${ }^{2}$ Satjito Raharjo, The Other Side of the Law in Indonesia, (Jakarta: Kompas), page 121.

${ }^{3} \mathrm{http}: / /$ tesishukum.com/pengertian-perlindungan-hukum-menurut-para-ahli/. Accessed on Friday, 17 March 2017 at 2.45 p.m.

${ }^{4}$ Ibid.

${ }^{5}$ https://www.merdeka.com/pendidikan/ini-pendapat-andi-hamzah-dan-simanjuntak-soal-perlindungan-hukum.html. Accessed on Friday, 17 March 2017 at 3.05 p.m.
} 
a result of the issuance of State Administration Decrees, including staffing disputes based on applicable laws and regulations."

Based on the provisions of Article 1 point 10 of Law No. 51 of 2009 above, what is meant by state administrative disputes are (1) disputes or conflicts that occur in the field of state administration (governance); (2) the dispute occurs between a state administrative agency/official and a private person or legal entity; (3) the dispute or conflict is caused by the issuance of a state administration decision; (4) this includes staffing disputes. Thus, the State Administrative Decree (KTUN) is the basis for the birth of a state administration dispute. KTUN is the main cause of the birth of state administrative disputes since without KTUN there is no administrative dispute. This is known as causality in which KTUN is the cause while disputes are the result. For this reason, KTUN is referred to as the object of state administrative disputes (objectum litis).

In the context of Law No. 30 of 2014 the term "government administrative disputes" is known which can be read in the provisions of Article 85 paragraph (1) and paragraph (2). However, Law No. 30 of 2014 does not determine the definitive definition of government administrative disputes. If referring to the definition of government administration as regulated in Article 1 point 1 of Law No. 30 of 2014, government administrative disputes are disputes that occur in the administration of government, especially in making decisions and/or actions by government agencies and/or officials.

The precise definition of government administrative disputes can be found in Supreme Court Regulation No. 2 of 2019 concerning Guidelines for Resolution of Disputes on Government Actions and Authority to Prosecute Unlawful Acts by Government Agencies and/or Officials (Onrechtmatige overheidsdaad). The Supreme Court Regulation stipulates that government administrative disputes are divided into 2 (two) which include (1) disputes over governmental actions; and (2) disputes against unlawful acts by government agencies and/or officials (Onrechtmatige overheidsdaad). Article 8 Supreme Court Regulation No. 2 of 2019 stipulates that each phrase "State Administration Decree" and the phrase "State Administration Dispute" in Law No. 5 of 1986 and the amendment must also be interpreted as "an act of government".

The definition of these two types of disputes can be seen in the provisions of Article 1 point 3 and point 4 of Supreme Court Regulation No. 2 of 2019. Article 1 Number 3 of the Supreme Court Regulation No. 2 of 2019 stipulates that "disputes over governmental action are disputes arising in the field of government administration between citizens and government officials or other state administrators as a result of government actions. Furthermore, Article 1 point 4 of the Supreme Court Regulation No. 2 of 2019 specifies that "disputes of unlawful acts by government agency and/or officials (Onrechtmatige overheidsdaad) are disputes which contain claims to state that the actions of government officials are illegal and/or null, or have no binding legal force and compensation in accordance with statutory provisions".

Based on these provisions, disputes over government actions constitute (1) disputes that occur in the field of government administration; (2) the dispute occurs between government agencies/officials and citizens; and (3) the dispute is caused by government actions. Thus, the main factor in the occurrence of disputes over governmental action is because government agencies/officials carry out government actions (bestuurshandelingen). For this reason, objectum litis from disputes over governmental actions is governmental acts.

The scope of state administrative disputes is certainly very broad. All legal actions of state administration officials in issuing concrete, individual, final and beshiking decisions that result in legal consequences are the object of state administrative disputes. In the dynamics of the development of administrative law, administrative decisions naturally include many aspects, bearing in mind that in a state of law, the decision of a state administration official is the legitimacy needed. Thus, every activity related to nomination, licensing and office activities in the government and private sector always deals with decisions that must be issued by state administrative officials. However, there are some cases where before a case is submitted to the State Administrative Court and/or to the State Administrative High Court the administrative effort must first be made. In Article 48 of Law No. 5 of 1985 concerning State Administrative Court, the status of administrative efforts is stated as follows:

a. In the event that a State Administration Agency or Officer is authorized by or based on statutory regulations to resolve certain Administrative Dispute, it is void or invalid with or without the available compensation and/or administrative claims.

b. The new court has the authority to examine, decide upon, and resolve the State Administration dispute referred to in paragraph (1) if all relevant administrative measures have been used.

Administrative effort is one of the spaces provided by law for justice seekers. According to Soemaryono, administrative effort is a complete evaluation of a state administration decision in terms of legality (rechtmatigheid) and opportunity (doelmatigheid). ${ }^{1}$

Moreover, based on ius contituentum, administrative efforts are defined as procedures specified in a

\footnotetext{
${ }^{1}$ Soemaryono and Anna Erliyana, in Ahmad Siboy.
} 
statutory regulation to resolve a State Administration dispute carried out within the government itself (not by a free judicial institution). ${ }^{1}$

According to Hari Sugiharto and Bagus Oktafian Abrianto, the reasons for using administrative efforts in the resolution of state administrative disputes are based on the following reasons:

"First, there is the concept of separation of state power from Montesquieu, which is divided into 3 (three) elements of power consisting of executive power (implementing law), judicial power (implementing judicial power) and legislative power (enacting the Law). The separation aims to guarantee the freedom of the people and prevent arbitrary actions from the authorities and prevent concentration of power on the state. Therefore, each power cannot interfere with each other's power. In this case government power should not be interfered with judicial power because the government knows best about government issues. Therefore, the resolution of state administrative disputes must first be resolved by the government itself through administrative means; Second, the task of government in principle is to provide public service rather than serving a lawsuit. Thus, if the state administrative dispute is apparently not resolved by the government, resolution through the judiciary is the ultimate tool (ultimum remidium); Third, in state administrative dispute resolution, the judiciary only tests from the legal aspect only (rechtmatigheid) while the government besides testing from the legal aspect (rechtmatigheid) also tests the aspects of efficiency and effectiveness (doelmatigheid)". ${ }^{2}$

Based on applicable law, administrative effort is one of the efforts that can be taken by justice seekers. Some legal basis for administrative efforts includes Article 48 of Law No. 5 of 1986 jo. Law No. 9 of 2004 concerning State Administrative Court, Law No. 30 of 2014 concerning Government Administration, Supreme Court Regulation No. 6 of 2018 concerning Guidelines for Resolution of Government Administrative Disputes after Administrative Efforts, Supreme Court Regulation No. 2 of 2019 concerning Guidelines for Resolution of Disputes on Government Actions and Authority to Prosecute Unlawful Acts by Government Agencies and/or Officials (onrechmatige overheidsdaad). It can be described in detail as follows:

Law No. 5 of 1986 is the formal law of administrative law. Therefore, the main point of regulation is regarding the procedure and mechanism of state administrative dispute resolution, especially the PTUN procedural law. Regulations regarding administrative efforts are only regulated in Article 48 of Law No. 5 of 1986 which determined that:

(1) In the event that a State Administration Agency or Officer is authorized by or based on statutory regulations

to administratively resolve certain state administrative disputes, the state administrative dispute must be resolved through the available administrative efforts.

(2) The new court is authorized to examine, decide upon, and resolve state administrative disputes as referred to in paragraph (1) if all relevant administrative measures have been used.

Furthermore, the explanation of Article 48 paragraph (1) determines that an administrative effort is a procedure that can be taken by a person or private legal entity if they are not satisfied with a State Administration Decree. The procedure is carried out within the government itself and consists of two forms. In the case of dispute resolution, it must be varied out by the supervisory agency or other agency from the issuing the relevant decision, then the procedure is called an "administrative appeal".

Examples of administrative appeals include:

Decision of the Tax Advisory Council based on the provisions in Staatsblad $1912 \mathrm{Nr} 29$ (Regeling van het beroep in belastings zaken) jo Law No. 5 of 1959 concerning the amendment of "Regeling van het beroep in belastings zaken".

Decision of the Personnel Advisory Agency based on Government Regulation No. 30 of 1980 concerning Discipline Regulation of Civil Servants.

Decision of the Committee of Resolution on Central Labor Dispute based on Law No. 22 of 1957 concerning Resolution on Labor Dispute and Law No. 12 of 1964 concerning Termination of Employment in Private Company.

Decision of the Governor based on Article 10 paragraph (2) of the Staatsblad Disturbance Act 1926 Nr. 226.

In the case of the resolution of the said State Administration Decree, it must be carried out by the agency or official of the State Administration who issued the decision, the procedure adopted is called "objection".

For instance, Article 25 of Law No. 6 of 1983 concerning General Provisions for Taxation is different from the procedures in the State Administrative Court. Then, the administrative appeal procedure or the objection procedure is carried out with a complete assessment in terms of the application of the law or in terms of policy by the agency that gave the decision.

From the provisions in the statutory regulations which are the basis for the issuance of the relevant State Administration Decree, we can see whether or not it is possible to take an administrative effort on an open State Administration Decree.

\footnotetext{
${ }^{1}$ Article 48 of Law No.5 of 1986 jo. Law No. 9 of 2004 concerning State Administrative Court

${ }^{2}$ Hari Sugiharto and Bagus Oktafian Abrianto, Administrative Efforts as Legal Protection for the People in State Administration Disputes, Journal of Law Arena Volume 11 No. 1 of 2018, pages 153-154
} 
In addition, the explanation of Article 48 paragraph (2) determines as follows:

"If all the procedures and opportunities mentioned in paragraph (1) have been followed and the parties concerned are still not satisfied, the matter can be sued and submitted to the Court".

These provisions contain at least 2 (two) legal norms/methods as follows:

a. The obligation to resolve state administrative disputes through administrative efforts is if the state administration agency/official is authorized by statutory regulations to resolve it through administrative efforts. On a contrario basis, if laws and regulations do not give authority to state administrative agency/official, there is no obligation to resolve state administrative disputes through administrative efforts. With this formula, the original/general law of administrative effort is "choice". Administrative efforts are mandatory if the laws and regulations provide authority to the agency/official to resolve it through administrative efforts. Thus, not all state administrative disputes must be resolved through administrative efforts but only certain state administrative disputes that are determined in the legislation.

b. The Administrative Court has the authority to adjudicate a state administration dispute if all required administrative efforts have been taken. It indicates that there are relative limitations on the competence of PTUN to adjudicate state administrative disputes. If the required administrative effort has been taken, the competent court of first instance is the state administrative high court in accordance with Article 51 paragraph (3) of Law No. 5 of 1986.

Based on the description above, not all state administrative disputes can be sued directly to PTUN. However, it must first review whether or not the basic regulations require administrative efforts. If the basic regulations require administrative efforts, then PTUN has absolute competence to judge if all of the required administrative efforts have been taken. Regarding this matter, Philipus M. Hadjon stated:

"There are two paths or two flows in litigation in front of the State Administrative Court. For state administrative decisions that do not recognize administrative efforts, the claim is addressed to the State Administrative Court as the first court of law. Meanwhile, state administrative decisions that recognize administrative efforts, the lawsuit is directly addressed to the State Administrative High Court". ${ }^{1}$

The flow of resolution of state administrative disputes based on Article 48 jo. Article 51 paragraph (3) of Law No. 5 of 1986 above can be observed in Figure 1.

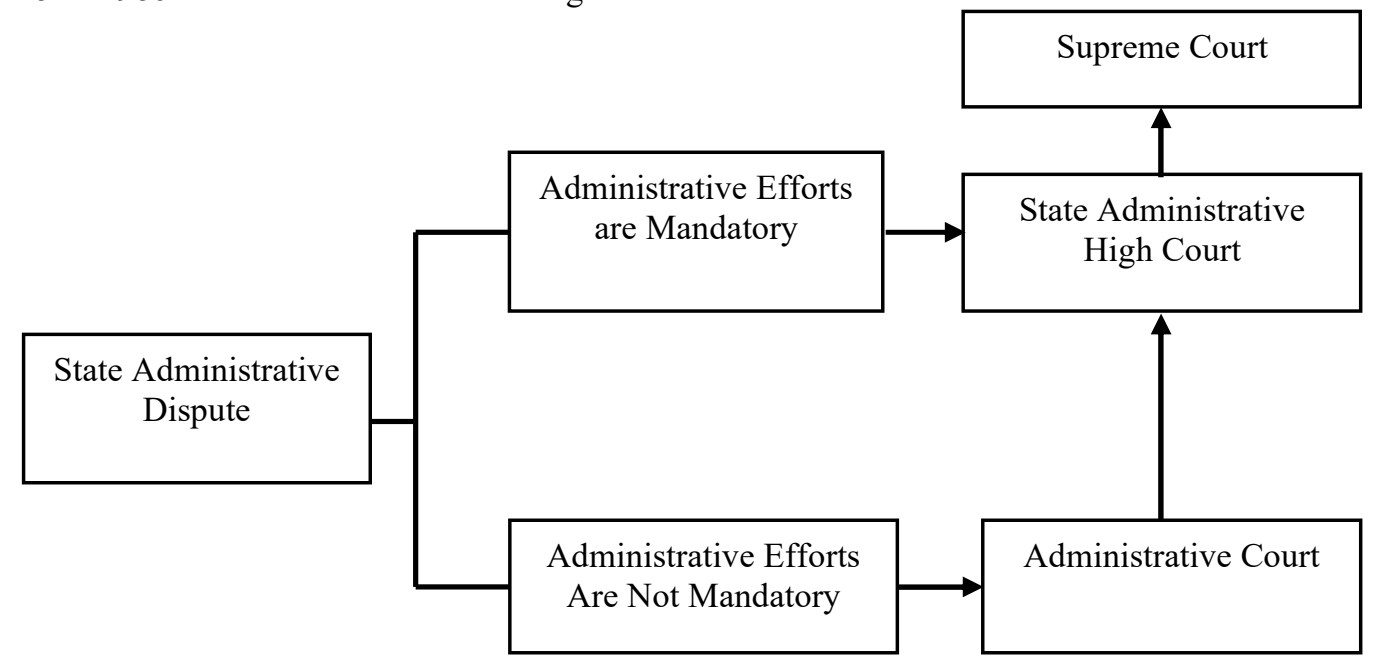

Figure 1. The Flow of Resolution of State Administrative Disputes based on Article 48 jo. Article 51 paragraph (3) of Law No. 5 of 1986

To implement the provisions of Article 48 of Law No. 5 of 1986, the Supreme Court issued a Circular Letter to the Supreme Court of the Republic of Indonesia No.2 of 1991 concerning the Implementation Guidelines for Provisions in Law No. 5 of 1986 concerning State Administrative Court. The administrative efforts specified in points IV.1 and IV.2 are as follows:

The Definition of Administrative Efforts is:

IV.1.

a. Submission of objection letter (Bezwaarscriff Beroep) submitted to the State Administration Agency/Official who issued the original decision (Stipulation/Beschikking);

b. Submission of administrative appeal (administratif Beroep) addressed to the superiors of officials or other agencies of the State Administration Agency/Officer who issues the decision, which is authorized to reexamine the disputed State Administration decision.

\footnotetext{
${ }^{1}$ Philipus M. Hadjon, et al, Introduction to Administrative Law in Indonesia, Yogyakarta: Gadjah Mada University Press, 2002 , page 317
} 
IV.2.

a. If the basic regulation only determines administrative efforts in the form of reviewing objection letters, a lawsuit against the relevant State Administration Decree is submitted to the State Administrative Court;

b. If the basic regulation determines administrative efforts in the form of objection letters and/or requires administrative appeal letters, a lawsuit against a State Administrative Decision which has been decided in an administrative appeal level is submitted directly to the State Administrative High Court in the first instance authorized.

Based on the description, there is a difference between the provisions of Article 48 and the Supreme Court Circular No. 2 of 1991. The difference lies in which court has absolute competence as the first level. If Article 48 jo. Article 51 paragraph (3) of Law No. 5 of 1986 stipulates that the state administrative high court is the first court for a state administrative dispute that requires administrative efforts, the Circular Letter of the Supreme Court of the Republic of Indonesia No. 2 of 1991 divides this into 2 (two): (1) if the administrative effort required is only objection, the state administrative court is the first level, and (2) if the administrative effort required is in the form of administrative objections and/or appeals, administrative decisions State enterprises that have been decided in the administrative appeal level are submitted to the State Administrative High Court as the first level.

The flow of resolution of state administrative disputes after the promulgation of the Supreme Court Circular of the Republic of Indonesia No. 2 of 1991 can be seen in Figure 2.

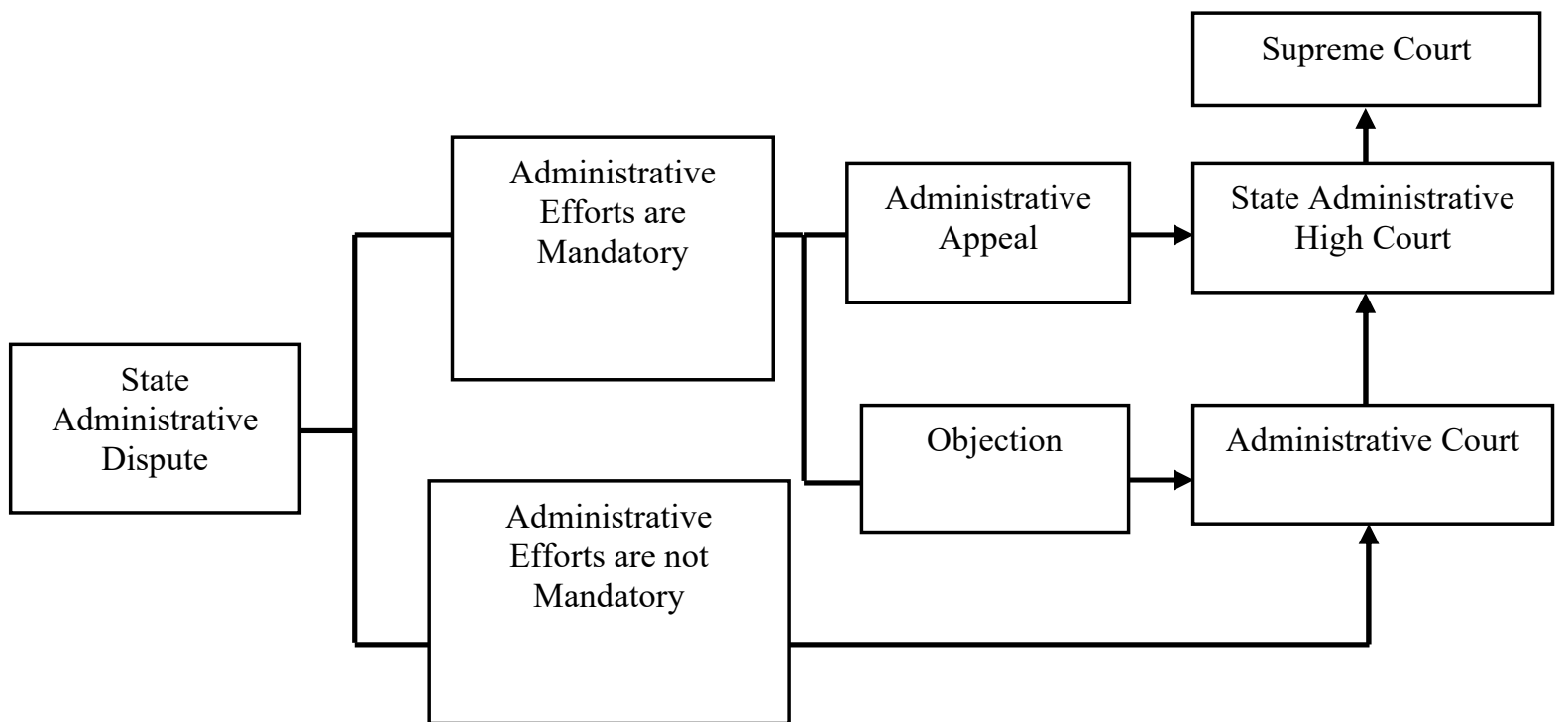

Figure 2. The flow of resolution of state administrative disputes after the promulgation of the Supreme Court Circular of the Republic of Indonesia No. 2 of 1991

To gain a more comprehensive understanding of state administrative dispute resolution using administrative efforts, here are a few examples:

a. State administrative dispute in regional head election

Resolution of state administrative disputes ${ }^{1}$ in the election of regional heads is determined in Article 154 of Law No. 10 of 2016 concerning the Second Amendment to Law No. 1 of 2015 concerning Stipulation of Government Regulation No. 1 of 2014 concerning the Election of Governors, Regents, Mayors Become Laws. The article stipulates that:

(1) Participants in election submit objections to the decision of the Provincial Election Commission (KPU) or the decision of the Regency/City KPU to the Provincial Election Supervisory Board (Bawaslu) and/or Regency/City Election Supervisory Committee (Panwaslu) within a maximum period of 3 (three) working days commencing from the decision of the Provincial KPU and Regency/City KPU are stipulated.

(2) Filing a lawsuit over a state administration dispute in election to the State Administrative High Court is carried out after all administrative efforts at the Provincial Bawaslu and/or Regency/City Panwaslu have been carried out"'

From this provision, the state administrative high court has the competence to resolve state administrative disputes in regional head elections. However, this authority can only be exercised after all administrative efforts

\footnotetext{
${ }^{1}$ According to Article 153 paragraph (1) of Law No. 10 of 2016, it was determined that "state administrative disputes in the general election are disputes arising in the field of election state administration between governor and vice-governor candidates, regent and vice-regent candidates, as well as mayor and deputy mayor candidates and Provincial KPU and/or Regency/City KPU as a result of the stipulation of Provincial KPU and/or Regency/City KPU decisions".
} 
(in the form of objections) to the Provincial Bawaslu and/or Regency/City Panwaslu have been carried out. The provision indicates that administrative efforts in the resolution of administrative dispute in the election of regional heads are mandatory.

The flow of resolution of state administrative disputes in regional head elections can be seen in the Figure 3.

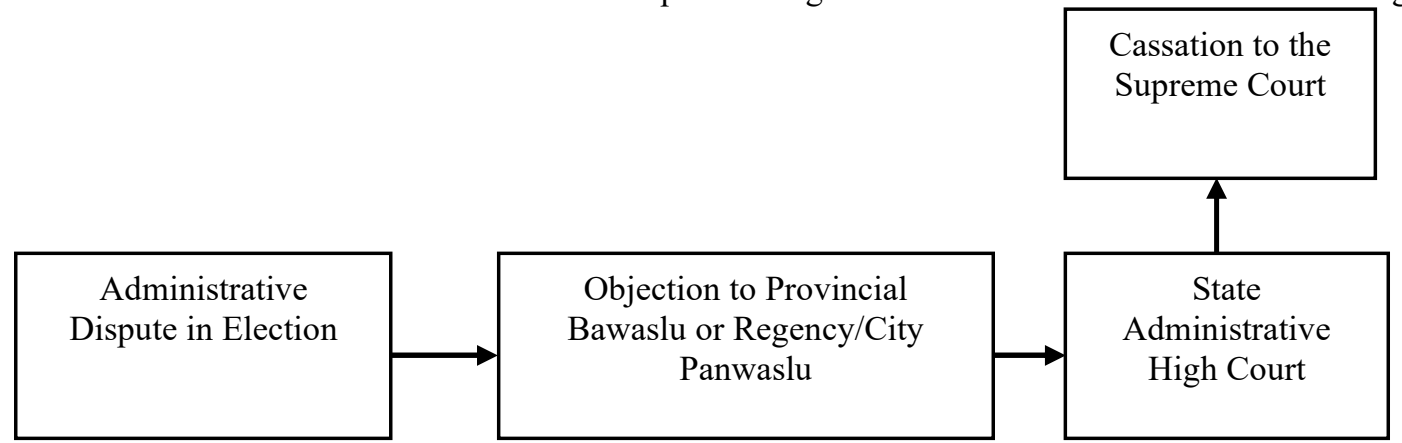

Figure 3. The Flow of Resolution of State Administrative Disputes in Regional Head Elections

b. Election process dispute

Resolution on election disputes ${ }^{1}$ is determined in Article 468 paragraph (1) of Law No. 7 of 2017 concerning Election. The article stipulates that "Bawaslu, Provincial Bawaslu, Regency/City Bawaslu are authorized to resolve disputes over the electoral process". By using this authority, Bawaslu, Provincial Bawaslu, Regency/City Bawaslu conduct mediation. If mediation is not agreed upon, adjudication is carried out. In accordance with Article 469 paragraph (1), it is determined that:

"The Election Supervisory Agency's decision regarding the election process dispute resolution is a final and binding decision, except for decisions on election process disputes relating to:

(1) verification of political parties participating in the election;

(2) determination of the permanent list of candidates for members of House of Representatives, Regional House of Representatives, provincial Regional House of Representatives, and regency/city Regional House of Representatives; and

(3) determination of election candidate pairs.

Article 469 paragraph (2) further stipulates that "if the dispute resolution process of the general election process as referred to in paragraph (1) letter a, letter b, and letter c conducted by Bawaslu is not accepted by the parties, the parties may submit legal remedies to administrative court". The authority of the state administrative court in resolving disputes over election process is regulated in Article 471 which specifies:

"The filing of a lawsuit, over the administrative dispute of election state as referred to in Article 470 to the state administrative court, is conducted after administrative efforts at Bawaslu as referred to in Article 467, Article 468, and Article 469 paragraph (2) have been used".

Based on these provisions, the party authorized to adjudicate disputes over the electoral process is the state administrative court. However, this authority can be exercised if all administrative efforts in Bawaslu have been used. The flow of dispute resolution process can be seen in Figure 4.

\begin{tabular}{|c|c|c|c|}
\hline $\begin{array}{c}\text { Election Process } \\
\text { Dispute }\end{array}$ \\
form of mediation-adjudication
\end{tabular}$\longrightarrow$ Administrative Court

Figure 4. The Flow of Dispute Resolution Process

Law No. 30 of 2014 places administrative efforts as one of the models of state administrative dispute resolution. For this reason, through administrative efforts in Law No. 30 of 2014, dispute resolution is a juridical instrument in providing legal protection for the people. Provisions regarding administrative efforts are specified in Article 75 to Article 78 of Law No. 30 of 2014. Article 75 paragraph (2) of Law No. 30 of 2014 determined that:

"Citizens who are harmed by decisions and/or actions can submit administrative efforts to government officials or their superiors who determine and/or make decisions and/or actions".

Based on the above formulation, the community members who are disadvantaged by the issuance of a decision or take action by a government agency/official 'can' propose administrative efforts to government officials or their superiors who make decisions or take action. The formulation of the article uses the word 'can' which according to Attachment II Number 267 of Law No. 12 of 2011 concerning the Formation of Laws and Regulations shows discretionary of an authority granted to a person or institution. Thus, the provisions of the

\footnotetext{
${ }^{1}$ In accordance with Article 466 of Law No. 7 of 2017, it was determined that "election process disputes include dispute that occurs between election participants and dispute that occurs between election participants and election organizers as a result of the issuance of KPU decisions, Provincial KPU decisions, and Regency/City KPU decisions".
} 
article mean that the community that is harmed by a government decision/action is given a choice to submit administrative efforts or directly file a lawsuit to the State Administrative Court. Resolution of state administrative disputes do not have to go through administrative effort procedures first, but the resolution can directly file a lawsuit to the state administrative court. In other words, administrative efforts are not required to be taken first, but it focuses on the choice of justice seekers.

Furthermore, according to the provisions of Article 75 paragraph (2) of Law No. 30 of 2014, administrative efforts consisted of objections (bezwaar) and administrative appeals. Objections are submitted by the applicant in writing to the governing agency and/or official who sets the decision. If the applicant does not receive the results of the objection, the applicant can submit an administrative appeal submitted to the supervisor of the official who issued the decision and/or take action. If the applicant does not accept the results of the administrative appeal decision, the applicant can file a lawsuit with the state administration court. This is determined in Article 76 of Law No. 30 of 2014 which determines that:

(1) Government agencies and/or officials have the authority to resolve objections to decisions and/or actions that are determined and/or carried out submitted by community members.

(2) In the event that the community members do not accept the resolution of objections by government agencies and/or officials as referred to in paragraph (1), the community members may submit an appeal to their supervisors.

(3) In the event that a community member does not accept an appeal resolution by the supervisor's official, the community member can file a lawsuit in court.

(4) Resolution of administrative efforts as referred to in article 75 paragraph (2) relates to the void or invalidation of decisions with or without claims for compensation and administrative claims.

The procedure for appealing objections and administrative appeals can be seen in Table 1 .

Table 1. The Procedure for Appealing Objections and Administrative Appeals

\begin{tabular}{|c|c|}
\hline Objection & Administrative Appeal \\
\hline $\begin{array}{l}\text { 1. The application is submitted in writing to the } \\
\text { agency/official that issues the decision no later } \\
\text { than } 21 \text { working days after the decision is } \\
\text { announced }\end{array}$ & $\begin{array}{l}\text { 1) Application is submitted to the supervisor of the } \\
\text { agency/official who issues the decision no later } \\
\text { than } 10 \text { working days after the decision on } \\
\text { objection is received }\end{array}$ \\
\hline $\begin{array}{l}\text { 2. Agency/official must complete the application no } \\
\text { later than } 10 \text { working days }\end{array}$ & $\begin{array}{l}\text { 2) Agency/official must complete the appeal within } 10 \\
\text { working days }\end{array}$ \\
\hline $\begin{array}{l}\text { 3. In the event that the agency/official does not } \\
\text { resolve the objection within } 10 \text { days, the } \\
\text { application is deemed granted }\end{array}$ & $\begin{array}{l}\text { 3) In the event that the agency/official does not } \\
\text { complete the appeal within } 10 \text { days, the application } \\
\text { is deemed granted }\end{array}$ \\
\hline $\begin{array}{l}\text { 4. In the case of an application being granted or } \\
\text { deemed granted, the agency/official is obliged to } \\
\text { make a decision in accordance with the } \\
\text { application no later than } 5 \text { working days after the } \\
\text { end of the grace period in } 10 \text { working days }\end{array}$ & $\begin{array}{l}\text { 4) In the case of an application being granted or } \\
\text { deemed granted, the agency/official is obliged to } \\
\text { make a decision in accordance with the application } \\
\text { no later than } 5 \text { working days after the end of the } \\
\text { grace period in } 10 \text { working days }\end{array}$ \\
\hline Read: Article 78 of Law No. 30 of 2014 & rticle 79 of Law No. 30 of 2014 \\
\hline
\end{tabular}

Based on the description above, according to the provisions of Article 76 paragraph (3) of Law no. 30 of 2014, the state administrative court has absolute competence to hear, examine and decide on state administrative disputes after administrative efforts in the form of objections and administrative appeals are taken. To exercise this authority, in 2016, the Supreme Court issued Circular No. 4 of 2016 concerning the Imposition of the Results of the 2016 Supreme Court Room Plenary Meeting as a Guideline for the Implementation of Duties for the Court. Point E, regarding the Legal Formulation of the State Administrative Chamber, determines that:

"State Administration Judicial Competence:

a. is authorized to hear cases in the form of lawsuits and petitions.

b. is authorized to prosecute unlawful acts by the government; i.e. unlawful acts committed by holders of governmental authority (Government Agency and/or Official) commonly referred to as onrechtmatige overheidsdaad (OOD).

c. State administrative decisions that have been examined and decided through administrative appeals are under the authority of the State Administrative Court.

Based on the provisions of the circular letter, one of PTUN's competencies is to adjudicate, examine and decide on state administrative decisions that have been decided through administrative appeals. The court that has the authority to examine is the state administrative court.

To strengthen the provisions in the circular, in 2018, the Supreme Court established Supreme Court Regulation No. 6 of 2018 concerning Guidelines for Resolution of Government Administration Disputes After Taking Administrative Efforts. The substance of the legal norms regulated in the Supreme Court Regulations is as follows: 
a. The State Administrative Court has the authority to adjudicate, examine, decide upon, and resolve government administrative disputes after making administrative efforts. This provision raises legal implications that (1) administrative efforts are no longer optional, but must be carried out on all administrative disputes, (2) administrative efforts are intended to begin with an objection, if the objection decision is not accepted, then submit an administrative appeal. It means that the court is only authorized if the petition does not accept an administrative appeal decision (all processes must be taken), and (3) the court authorized to hear, examine, decide and resolve is the administrative court as the first court.

b. The court examines, hears, decides, and resolves government administrative disputes according to the provisions of the procedural law which applies in court unless otherwise stated in the provisions of the applicable laws and regulations.

c. The court in examining, adjudicating, deciding, and resolving government administrative disputes uses the basic rules that govern these administrative efforts. If the basic regulation does not specify it, the provisions contained in Law No. 30 of 2014 is used.

d. Third parties with an interest and who are harmed by the administrative effort decision can file a lawsuit against the decision on the result of the administrative effort and it cannot be filed against a court decision which has permanent legal force.

e. The grace period for filing a lawsuit is 90 days after the decision on administrative efforts is received by the community or announced by the agency/official handling the administrative effort.

Based on the description above, the flow resolution of state administrative disputes after the enactment of Supreme Court Regulation No. 6 of 2018 can be seen in Figure 5.

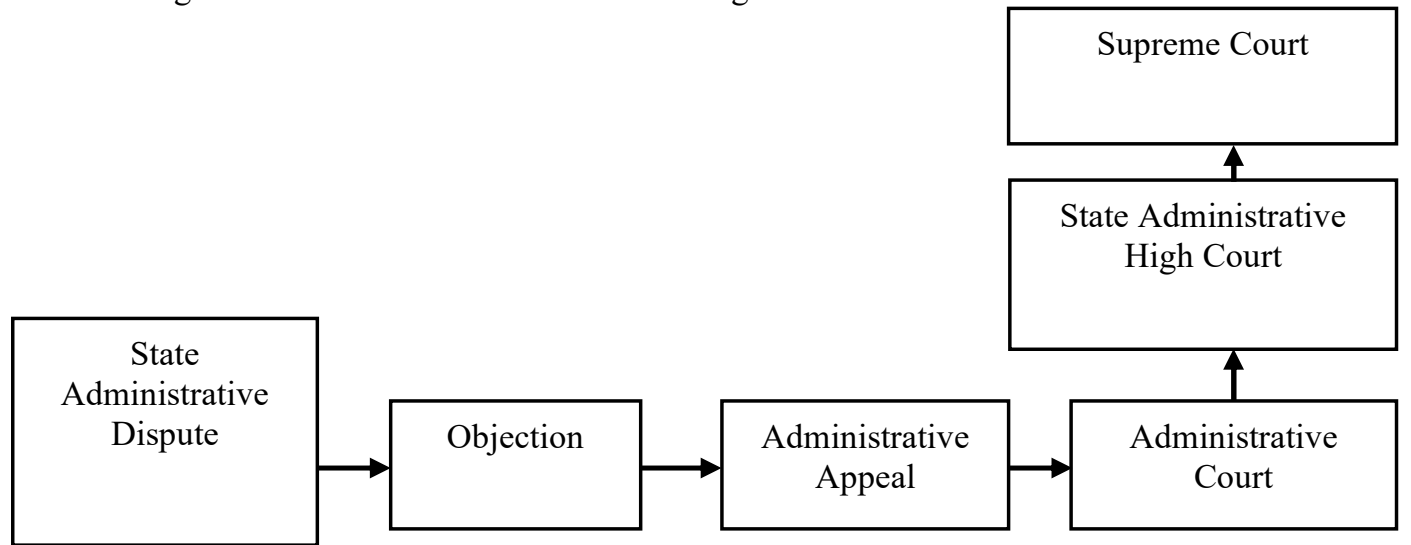

Figure 5. The Flow Resolution of State Administrative Disputes After the Enactment of Supreme Court Regulation No. 6 Of 2018

The procedure regarding the administrative effort changed again after the enactment of Supreme Court Regulation No. 2 of 2019 concerning Guidelines for Resolution of Disputes on Government Actions and Authority to Prosecute Unlawful Acts by Government Agencies and/or Officials (Onrechtmatige Overheidsdaad). Article 2 paragraph (2) of the Supreme Court Regulation stipulates that the State Administrative Court is given the authority to adjudicate, examine, decide on, and resolve disputes over government actions after taking administrative measures in accordance with Law No. 30 of 2014 and Supreme Court Regulation No. 6 of 2018. However, if the statutory provisions specify specifically regarding administrative efforts, the dispute over the said government action is tried by the State Administrative High Court as the first court (vide Article 2 paragraph 3). 


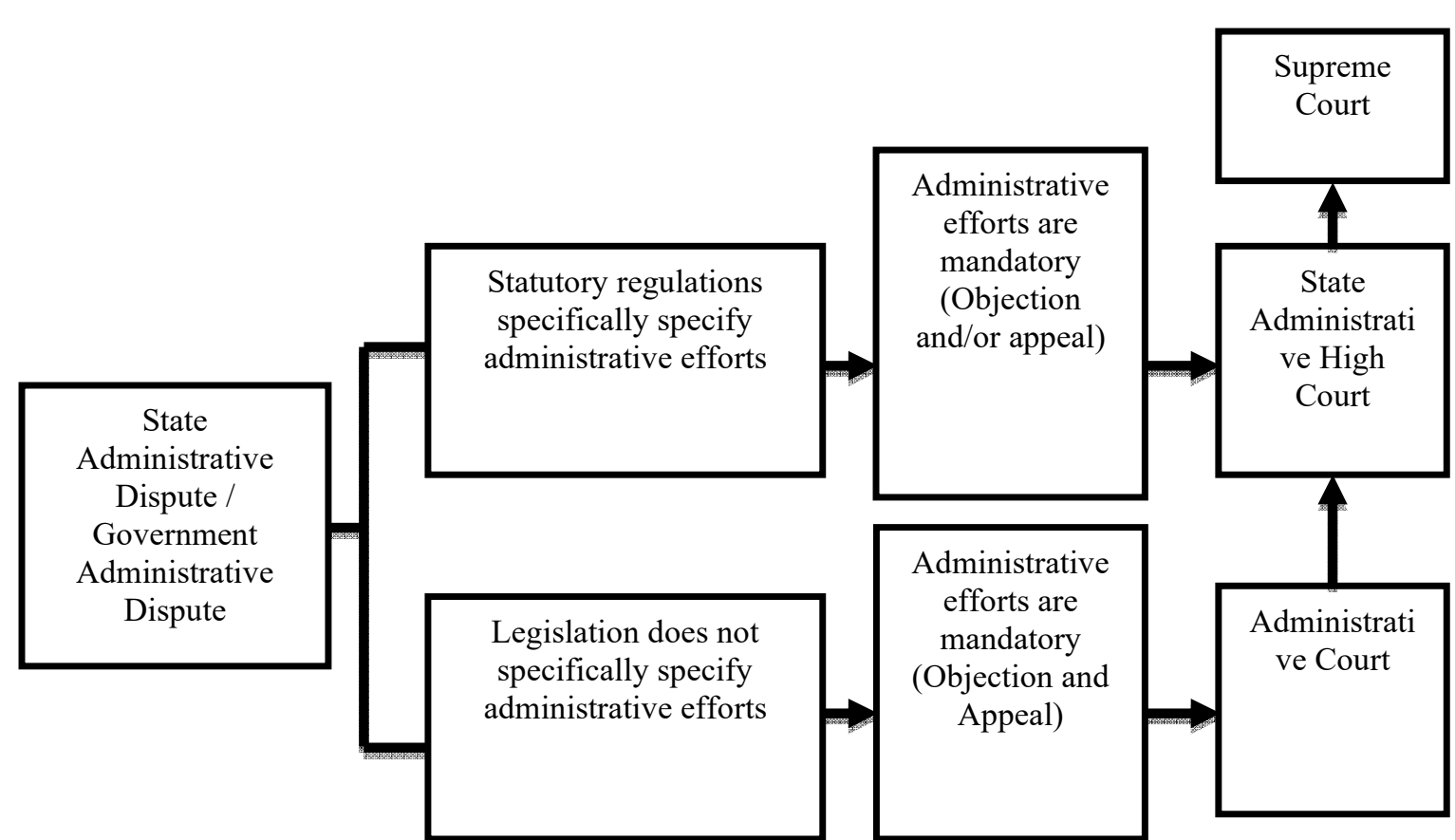

Figure 6. The Procedure Regarding the Administrative Effort

\section{Conclusion}

Administrative efforts are one form of legal protection for justice seekers as regulated in Law No. 5 of 1986 concerning State Administrative Court, Law No. 30 of 2014 concerning Government Administration, Supreme Court Regulation No. 6 of 2018 concerning Guidelines for Resolution of Government Administration Disputes After Taking Administrative Efforts, Supreme Court Regulation No. 2 of 2019 concerning Guidelines for Resolution of Disputes on Government Actions and Authority to Prosecute Unlawful Acts by Government Agencies and/or Officials (onrechmatige Overheidsdaad). Thus, administrative efforts must be taken by justice seekers before submitting cases to the State Administrative Court and the State Administrative High Court. This administrative effort is intended to screen cases that must be tried by the State Administrative Court and/or the State Administrative High Court so that the burden of incoming cases can be minimized.

\section{References}

Abdul Kadir Muhammad, 2004, Hukum Dan Penelitiian Hukum, Bandung: PT Citra Aditya

Achmad Ali, 2009, Menguak Teori Hukum (Legal Theory) dan Teori Peradilan (Judicialprudence), termasuk interpretasi Undang-undang (Legisprudence), Jakarta: Kencana Prenada Media Group

Philipus M. Hadjon, 1987, Perlindungan hukum bagi rakyat di Indonesia: sebuah studi tentang prinsipprinsipnya, penangananya oleh pengadilan dalam lingkungan pengadilan umum dan pembentukan peradilan administrasi.( Surabaya: PT Bina Ilmu,),

Satjito Raharjo, Sisi Lain Dari Hukum Di Indonesia, (Jakarta: Kompas)

Sirajuddin dkk, 2016, Hukum Administrasi dan Pemerintahan Daerah, Malang: Setara Press,

Sudikno Mertokusumo, 2006, Penemuan Hukum: Suatu Pengantar, Yogyakarta: Liberty,.

Ridwan, 2009, Tiga Dimensi Hukum Administrasi dan Peradilan Administrasi, (Yogyakarta: FH UII Press)

Soemaryono dan Anna Erliyana, 1999, Tuntunan Praktek Beracara Di Peradilan Tata Usaha Negara, (Jakarta:

PT. Pramedya Pustaka)

Tamanaha, Brian Z, 2006, On The Rule Of Law, History, Politics, theory, Cambridge University Press.

Titon Slamet Kurnia, 2015, Interpretasi Hak-hak Asasi Manusia Oleh Mahkamah Konstitusi Republik Indonesia, Bandung: CV. Maju Mundur

Thomas Morawets, 1980 The Philosophy of law, New York: Macmillan Publishing

Peter Mahmud Marzuki, 2010, Penelitian Hukum, Jakarta : Kencana,

Philipus M. Hadjon Dan Tatiek Sri Djatmiati,2008, Argumentasi Hukum, Yogyakarta: UGM Press

Pusat Penelitian Dan Pengembangan Mahkamah Agung Republik Indonesia, 2013 Mahkamah Agung sebagai Judex Juris ataukah Judex Factie: Kajian Terhadap Asas, Teori dan Praktek, Jakarta: Mahkamah Agung

Yuslim, 2015 Hukum Acara Peradilan Tata Usaha Negara, Jakarta: Sinar Grafika.

Zairin Harahap,1997, Hukum Acara Peradilan Tata Usaha Negara, Jakarta, PT RajaGrafindo. 


\section{Regulation}

The 1945 Constitution of the Republic of Indonesia

Law No. 32 of 2004 concerning Regional Government (State Gazette of the Republic of Indonesia of 2004 No. 125)

Republic of Indonesia Law No. 5 of 2004 concerning Amendments to Law No. 14 of 1985 concerning the Supreme Court (Republic of Indonesia State Gazette 2004 No. 9)

Law No. 9 of 2004 concerning Amendments to Law No. 5 of 1986 concerning State Administrative Court (State Gazette of the Republic of Indonesia No. 4380)

Republic of Indonesia Law No. 3 of 2009 concerning the Second Amendment to Law No. 14 of 1985 concerning the Supreme Court (State Gazette of the Republic of Indonesia 2009 No. 3)

Law No. 48 of 2009 concerning Judicial Power (State Gazette of the Republic of Indonesia Number 5076)

Law No. 51 of 2009 concerning the Second Amendment to Law No. 5 of 1986 concerning State Administrative Court (State Gazette of the Republic of Indonesia 2009 No. 160)

Law No. 12 of 2011 concerning Formation of Laws and Regulations (State Gazette of the Republic of Indonesia of 2011 No. 82)

Law No. 30 of 2014 concerning Government Administration (State Gazette of the Republic of Indonesia 2014 No. 29235)

Supreme Court Regulation No. 6 of 2018 concerning Guidelines for Resolution of Government Administration Disputes after Taking Administrative Efforts (State Gazette No. 1586 in 2018).

Supreme Court Regulation No. 2 of 2019 concerning Guidelines for Resolution of Disputes on Government Actions and Authority to Prosecute Unlawful Acts by Government Agencies and/or Officials (onrechmatige Overheidsdaad).

Indonesian Dictionary, (Surabaya: Cahaya Agency). 